\title{
Research on Marxist Outlook of Nature and Environmental Construction of New Socialist Countryside in Hainan
}

\author{
Hong Suo \\ School of Economics and Management, Hainan Normal University, Haikou, 571158, China
}

Keywords: Marxism, Outlook of nature, Hainan, New socialist countryside, Environmental construction

\begin{abstract}
With Chinese economic development in recent years, ecological problems seem to be more severe and even influence the normal work and life of human beings. Under this situation, Marxist outlook of nature arouses the attention of people again. It is a subject treating the relationship between human beings and nature and explaining such relationship with Marxist world view and methodology. This paper analyzes Marxist outlook of nature, applies it to environmental construction of new socialist countryside in Hainan and expects to provide some beneficial references for environmental construction of new socialist countryside.
\end{abstract}

\section{Introduction}

In recent years, Chinese ecological environment has severe problems. The degradation of ecological environment has produced adverse influence on the production and life of Chinese people and even the international image of China. Facing severe ecological problems, the $17^{\text {th }}$ CPC National Congress put forward the great call for the construction of "socialist ecological civilization". In the establishment of socialist ecological civilization, Marxist outlook of nature has important guiding significance and can provide scientific guidance for environmental construction of new socialist countryside in Hainan.

\section{Main ideas of Marxist outlook of nature}

According to human development history, human beings have experienced two development stages - agricultural civilization and industrial civilization. Currently, adequate importance has been attached to "ecological civilization". ${ }^{[1]}$ Marxist outlook of nature analyzes the relationship between human and nature scientifically and puts forward the methodology of great guiding significance. It has great guiding significance for the construction of "ecological civilization" in the current stage.

\section{Marx put forward the inference of dual nature and dual position of human beings in nature}

According to Marx's opinions on humanity, Marx divided the property of human into two types: on the one hand, human beings have social property. They live in the society and belong to the society. On the other hand, Marx thought that human beings have certain natural property and also belong to the nature. ${ }^{[2]}$ Due to the influence of living conditions of human beings, they have "dual positions" correspondingly. First, according to the opinion of Marx, as natural persons, human beings live in nature and need to get on with nature and handle the relationship with nature correctly. Human beings originate from nature and is a result of natural evolution. They belong to a part of the natural world. Second, human beings have social property. Marx thought that human society is a result of socialization and transformation of nature conducted by human beings. Marxist outlook of nature uses materialistic opinions to understand the relationship between human and nature correctly. It has fundamental differences from the outlook of nature of old materialism and idealism.

\section{Marxist outlook of nature adheres to subjectivity principle}

Practical viewpoint is an important viewpoint of Marx. In this viewpoint, Marxism believes that human beings have subjective initiative and are the subject of practice. ${ }^{[3]}$ They transform the nature through their labor practice. Different from human beings, nature is the object understood and 
transformed by human beings in their relationship. The practice way of human beings meeting the law of nature can achieve positive practical results. On the contrary, human beings will be punished by nature if damaging the law of nature. Therefore, the status of relationship between human and nature depends on the property of practice of human subject to a great extent. To get on well with the natural world, it is necessary to respect nature and coexist with nature harmoniously in the process of natural transformation.

\section{Idea of Marxism about humanized nature under practical conditions}

According to Marxist opinions, the relationship among human, nature and society is "human nature - society". Society is the result of natural transformation conducted by human. In their relationship, practice is the link connecting them. Only after transformation can the natural world establish a relation with human beings and exist as an existence object of human beings. For human beings, the natural world without their practice mark does not have great value. Therefore, according to Marx's opinions, nature to be studied by human beings is the natural world transformed by people in practice which is humanized nature. In the current social development, some people do not have accurate natural ideas. They mix humanized nature and raw nature and fail to understand the relationship between human and nature scientifically. Therefore, they are opponent to Marxist outlook of nature.

\section{Marx's judgment on natural productivity}

According to opinions of Marxist outlook of nature, nature has certain productivity. Both natural environment and natural conditions play a key role in social development. Generally, the productivity of nature is called as "natural productivity". In the opinion of Marx, natural conditions mainly refer to some physiological and psychological situations of human beings, such as appearance. Besides, natural conditions also include natural environmental conditions involved in human life. Labor productivity is the production efficiency of laborers. It mainly refers to the production amount of laborers in the production process and is realized by human beings to a great extent. Therefore, labor productivity and natural conditions are closely related. The improvement of labor productivity depends on the improvement of natural conditions. In addition, the improvement of social productivity should turn to the power of nature which can be considered as natural phenomena such as hydraulic power and wind power. In the current society, natural force has been widely used. For example, wind power and hydraulic power are used for generating electricity, which can provide power for production activities of human society and promote its development. The most typical one is agricultural production. For example, in agricultural development, productivity not only is related with the efficiency of laborers, but also is influenced by natural conditions to a great extent. For agricultural development. The improvement of productivity in the agricultural society mainly aims at making up for the destructive effect of natural force and is a replaceable compensation for the destruction of natural force. According to the analysis on social productivity from this perspective, natural productivity is one of the important factors influencing social productivity.

\section{Marxist idea of historical task about "two major reforms"}

In the opinion of Marx, human beings are always faced with two major reforms in the development of human society - reconciliation between human and nature and reconciliation among human beings. ${ }^{[4]}$ Marx found this important phenomenon through his own observation and therefore had more in-depth and scientific understandings of nature. Marxist outlook of nature has been enriched. As far as Marx can see, human history mainly includes two basic directions - natural development history and human development history, which are interconnected and restrict each other. According to the thought of Marxism, in terms of the understanding of ecological environment, the wrong opinion that ecological environmental problems are determined by the level of productivity development of human beings will be abandoned and the correct viewpoint that ecological environmental problems are closely connected to the practice way of human beings to a great extent can be seen. Therefore, we can master reasons for ecological problems in the human society in 
essence and adopt scientific methods in environmental construction by using Marxist outlook of nature as guiding thought in environmental construction of new socialist countryside.

\section{Guide environmental construction of new socialist countryside in Hainan with Marxist outlook of nature}

The current construction of new socialist countryside has many features. Environmental construction is one of the main contents of construction of new socialist countryside. The basic requirement of environmental construction of new socialist countryside is clean and tidy village. Marxist outlook of nature understands the relationship between human and nature correctly and masters the essence of ecological problems in essence. Therefore, it is necessary to adhere to the significance of methodology of Marxist outlook of nature and use scientific and reasonable methods for environmental construction of new socialist countryside in Hainan.

\section{Background of environmental construction of new socialist countryside in Hainan}

Great importance has been attached to environmental construction of new socialist countryside in Hainan by the Party Central Committee. In 2006, the minister of the Propaganda Department of the Central Committee of the CPC, Liu Yunshan gave important instructions on environmental construction of new socialist countryside in Hainan, i.e. required Hainan Province to adhere to the development principle of "comprehensive construction around the center" during environmental construction of new socialist countryside. ${ }^{[5]}$

\section{Construction thoughts under the guidance of Marxist outlook of nature}

Marxist outlook of nature has scientific guiding significance. Therefore, it is required to adhere to basic thesis of Marxist outlook of nature in environmental construction of new socialist countryside in Hainan. Marxist outlook of nature divides environment into natural environment and social environment. Therefore, environmental construction of new socialist countryside should be implemented in these two aspects.

\section{Conduct scientific planning}

First, the relevant department should investigate the local geographical environment, communicate with local people actively and listen to their opinions before the construction of new socialist countryside. The relevant department should organize some experts for the design of planning scheme on this basis. In the planning and design, it is necessary to adhere to the construction principle of regional coordination, fully consider local historical and cultural customs and life tradition of residents and design according to local conditions. Moreover, it is required to integrate buildings in the design, guarantee the aesthetic property of house layout and make sure that corresponding infrastructure construction can facilitate the life of people to the greatest extent. Finally, it is necessary to adhere to the principle of environmental protection in the construction under the condition of respecting social culture and manners and customs of local people and save social resources. For example, as Hainan is an accumulation area of the Li nationality. Living habits of the nationality must be respected in the construction process of new countryside.

Protect ecological environment

In environmental construction of new socialist countryside, rubbish is an important factor influencing social environment. Therefore, a scientific method should be used to dispose household garbage. First, for straw and excrement of human and livestock in the countryside, biogas digester can be built in the construction of new countryside. Under this condition, it can dispose household garbage and meanwhile provide fuel for villagers. Second, for other household garbage, waste storage tank can be built. Then, villagers can throw rubbish into the tank, thus avoiding littering and influencing rural environment. Finally, according to development features of Hainan Province, human and livestock can be separated. Special breeding bases can be established. Under this situation, excrement of livestock can be disposed intensively and meanwhile the environment can be beautified. 


\section{Conduct reasonable road planning}

Road is an important constituent part in the construction of socialist countryside, which directly influences environmental structure of new countryside. Convenient road can provide great convenience for the life of villagers. In the construction of rural roads, it is necessary to conduct scientific planning in advance and minimize the influence on environment. In addition, besides some major roads, it is necessary to build some paths to connect different peasant households and meanwhile do road greening work well. Some green plants or flowers can be planted along roads, which can purify and beautify rural environment.

Conduct planning of rural architectural style

Building construction in new socialist countryside is also an important constituent part of rural environment. This requires the relevant department to design building construction according to features of the countryside in Hainan in the process of rural housing construction. First, planners should understand climatic characteristics of Hainan. Hainan Island has tropical monsoon climate, a lot of precipitation mainly in summer and high temperature all year around. Therefore, buildings should be tall and windows should be large. Hainan Island has humid climate, which is good for ventilation and moisture protection. In addition, the roof should better be pitched, which is good for water drainage. Second, planners should handle the planning of former address and new district well and protect some historical buildings. Finally, designers should use environmentally friendly materials in the design.

Make the environmental in new countryside tend to be artistic

Hainan Island is a tourist resort which attracts a lot of tourists every year especially in winter. Under such conditions, planners are required to provide rural environment with artistic features in construction. Hainan Island has tropical climate and green plants in four seasons. In particular, coconut trees have become a symbol of Hainan. Rural construction should make social and natural environment integrated with each other harmoniously based on such natural environment. In addition, economic factors should be considered in the process of environmental construction of new socialist countryside. Some forms of tourism such as rural tourism and mango picking can be developed with favorable natural environment. Some commercial crops can be chosen in park greening so that they can produce economic benefits for villagers while beautifying the environment.

\section{Conclusion}

Marxist outlook of nature is a scientific point of view on the relationship between human and nature, which has vital guiding significance for handling such relationship. Therefore, it is required to adhere to Marxist outlook of nature in environmental construction of new socialist countryside in Hainan.

\section{Acknowledgments}

This paper is a project of Research on Marxist Outlook of Nature and Environmental Construction of New Socialist Countryside in Hainan, No. HNKY2014-45.

\section{References}

[1] Bai Xiuming. Discussions on Principles of Ecological Moral Construction in New Socialist Countryside in Regions Inhabited by Ethnic Groups. Economic Field, 2014,(6):7-7.

[2] He Chao. Research on Strategies for Construction of Eco-town in Field of Marxist Ecological Philosophy. Jiangsu University, 2014.

[3] Xiong Fang. An Understanding of "Beautiful China” - Based on Marxist Outlook of Nature. Economic and Social Development, 2013,11(2):6-8. 
[4] Shi Lei, Zhao Yuxia. Ecological Connotations of Marxist Outlook of Nature - Understanding in Field of Ecological Marxism. Philosophy Study on Science and Technology, 2012,29(2):97-101.

[5] Li Qing. Discussions on Marx’s Practical Relation between Human and Nature - Comment on Western Marxist Outlook of Nature. Journal of the Party School of Shengli Oilfield, 2014,(3):42-44. 